\title{
Dynamics of Globalization: Linguistic and Cultural Perspectives in Nigeria
}

\author{
Chuka Chukwube \\ University of Lagos, Lagos, Nigeria
}

\begin{abstract}
The word globalization and what it stands for is no longer new in the world of today. However, there is still no universal definition of globalization. This has led to erroneously or otherwise, the interchangeable use of the word with internationalization and liberalization. Suffice it therefore to say that globalization is the transcendence of the economic, political, environmental, social and cultural constraints across territories. The task of this paper is essentially to ascertain the level of involvement of Africa via Nigeria in this new international economic power and order. This is necessary because Nigeria particularly, has become a good consumer of information technology which is an essential ingredient of globalization. The issue then is how prepared are the Nigerian languages in the challenges of information technology as demanded by globalization. What are the implications of the order to Nigerian cultural revival and development?
\end{abstract}

Keywords: globalization, internationalization, cultural, Nigeria, liberalization

\section{Introduction}

For a clearer understanding of the significance of globalization in Africa in general and in Nigeria in particular, there are two premises that we must explore.

The first premise is to realize that today's globalization is actually not the first stage of outside invasion of Africa which not only affected African integral development, but also had negative consequences on the continent indeed, globalization can correctly be considered as the fourth stage.

In analyzing these stages, Henriot (2000) said that the first stage was the period of slavery, during which the continent's most precious resources, African women and men, were stolen away by global traders, slavers, working for the benefit of Arab, European and North American countries. It is estimated that about 10 million slaves were forcefully pulled out of the continent. Henriot continued by saying that the second stage was "the period of colonialism, when British, French, Belgium, Portuguese, Italian, and German interests dictated the way to map boundaries were drawn, transportation and communication lines established, agricultural and mineral resources exploited, religious and cultural patterns introduced". The third stage he called neo-colonialism which according to him Pope Paul VI called "the form of political pressures and economic suzerainty aimed at maintaining or acquiring dominance”. The fourth stage is globalization, which according to him, is "characterized by an integration of the economies of the world through trade and financial flows, technology and information exchanges, and movement of people".

The second premise, which is our main point of discourse, is globalization, which in the views of the

Chuka Chukwube, Ph.D., Department of European Languages, University of Lagos. 
analyst Henriot:

is not working for the benefit of the majority of Africans today. He insists that "while globalization has increased opportunities for economic growth and development in some areas, there has been an increase in the disparities, and inequalities experienced in Africa. (Henriot, 2000, p. 207)

But in other to be deeply engulfed in the analysis and views of Henriot it is imperative to note that the task of this piece is essentially to determine the level of development and otherwise of languages of globalization in Africa vis-à-vis Nigeria; how has the lack of seeming development of Nigeria and indeed Africa from benefiting materially the gains of globalization. It is after ascertaining this that we would review the impact of globalization in our economy, politics, culture, and technological innovation.

This leads us to the question of whether Nigeria has a language or languages, developed or otherwise. Nigeria is a country made up of large number of independent nationalities. Emenanjo (2001) says that the exact number of the primordial nationalities to be found in Nigeria is not known given language shift. Equally unknown is the precise number of languages spoken by these nationalities, wing of language death. But it is not arguable that Nigeria is a sociolinguistic giant. According to Ferguson (1966), Nigeria holds within her international boundaries a multiplicity of linguistic and ethnic families which present a fascinating example of linguistic heterogeneity with a picturesque mosaic of some 394 distinct languages. In his own study Osaji (1979b) submits that the population of Nigeria, which increases by over a million every 18 months, is almost entirely African belonging to some three hundred and sixty-eight (368) linguistic groups, the principal ones being Hausa, Igbo, Yoruba, and Fulani. On the level of development of these main languages, Ferguson's (1968) is of the opinion that Nigerian languages are at varying stages of development from purely "local", "pre-literate", or "oral" languages to written to national and regional languages, with varying corpora of written literatures among other types of texts.

The importance of language in national development cannot be over emphasized. Chumbo (1990) says that the role of the language used as medium of instruction in the educational process is very important because the effectiveness of the educational or training programme depends on whether effective communication has taken place between the teacher and the learner or not. Thus, education by means of an appropriate language medium provides knowledge, skills, and value necessary for man to become an effective agent of change. Much on this, however, would be discussed when we come to the language policy of Nigeria in the later part of this work.

Making further clarification of languages used in Nigeria, Emenanjo (2001) maintains that they are classified in different ways and with different parameters and for different reasons or purposes. He cited the example of Adekunle (1972), Osaji (1979b), Brann (1977), Olagoke (1980), Williamson (1983), and Emenanjo (1986). After modifying the classifications of Williamson's (1983) and Brann's (1986), he came up with the following five broad groups of languages used in Nigeria:

(1) The "foreign" or "exoglossic" languages (or "exolects" or "endolects"); English in its continuum, French and Arabic;

(2) The "very large" or “decanillionaires" (or “demolects”, i.e., language spoken by more than ten million people); Hausa, Igbo, Yoruba, and Nigerian pidgin;

(3) The "large" languages or "millionaires" (or “demolects", i.e., Languages spoken by more than one million people); Edo (Bini), Ibibio, Fulfulde, Izon, Kanuri, Nupe, and Tiv; 
(4) The “medium” languages or “centimils" or “ethnolects”, i.e., languages spoken by more than 100,000 people); Idoma North, Nembe, Igalla, Urhobo, Bokwai, Kalabari, Ngas, Abuan, Bekwarra, Ebira, Ekejuk, Efik, Kha, Engenni, Junkun of Talcun, Bura, Mambilla, Kaje;

(5) The "small” languages (“chtonolects", i.e., languages spoken by less than 10,000 people) and all other languages used in Nigeria but not listed in (1)-(4) above.

Further classification were made on the "minorities" or "minor" languages by Agheyisi (1986) who says that "minor" languages number about 380 are "spoken by about $20 \%$ of the total national population". She therefore classified the Nigerian languages thus:

(1) The “developed languages”, i.e., those with well-established orthographies, standard varieties, long traditions of writing, large and varied corpora of written texts and sophisticated and dynamic metalanguages. Three languages, the decamillionaires belong here;

(2) The “developing” languages, i.e., those with recent but settling orthographies, fairly recent traditions of writing, incipient standard varieties, some amount of written texts and nascent metalanguages. Included in this class are all the millionaires, some of the continents and most of the minorities;

(3) The "undeveloped" languages, i.e., those that have no standard(ized) orthographies, universally accepted within the culture areas, no standard varieties, no written texts and no metalanguages. Nigerian languages not covered in (1) and (2) belong here.

It is imperative to refer to these analysis not only to understand the linguistic complexity of the country but also to point out that the sociolinguistic profiles of respective languages with a view to determining the preparedness of the so-called national languages to challenges of globalization for any country to conveniently and adequately compete in this new world order depends on "how seriously her indigenous languages (and cultures) are developed and used as media of communication in our work-a-day lives and in academic and scientific discourse. According to Emenanjo (2001), English can help us realize all the fundamental objectives—political, economic, social and educational—of the Nigerian nation. But English is an elitist language spoken in all its elects by not up to 20 percent of the Nigerian population. Therefore, English cannot be the language of mobilization in Nigeria and in Africa because of low percentage of its users. Study has shown that the few creative works written in the writers native languages attracted more mass mobilization than ones written in English and French. Notable among such works are Ngugi Wa Thiongo's creative works in Gikuyn, the Wolof films of Sambene Osamane and Herbert Ogunde's Yoruba Ronu. Apart from this revelation, many Africans consider works written in the language of the colonialists or neo-colonialists as petit bourgeois luxuries out of the reach of the common man.

Commenting on the need to develop Nigerian national languages, Emenanjo (2001) further said that

we do hope that the people we are looking forward to, in Nigeria, to perform the magic of technological transfer are not people who know a little English and less Nigerian languages. Before people think we are being mawkish, and stupidly sentimental about the potentials of Nigerian languages as agents of change and national development, we need to once again emphasize the point that good citizenship, creative and responsible citizenry and a technologically sensitive polity can only be realized if the hoi polloi are spoken to and taught in their indigenous languages and not in the exoglossic languages of bureaucracy. (p. 89)

It is people who like Emenanjo using all available channels have succeeded in drawing the attention of the Nigerian government in a formation of a National policy on education. After all, no country ever develops with a foreign language. Agreeing with this notion, Banjo (1995) says that the choice of a national language is in 
turn, expected not only to do a lot for the national psyche but also facilitate national mobilization for development which, in term, will enhance the production of more wealth and launch the nation into the world's top league of developed nation". In order to ascertain the efforts of the Nigerian government in making her national languages globalization compliant, the review of Nigerian National Policy on Languages becomes imperative.

\section{National Policy on Languages}

In spite of all the clamour and seeming importance of a national language or languages for national development and global interactions, Nigeria is yet to have a well-articulated de jure national language policy that is contained in one document. However, government's views on this all important issue can be found in a number of national documents such as the constitution of the Federal Republic of Nigeria (1999) Chapter II Section 55; 97, the Government Views and Comments on the Findings of the Recommendations of the Political Bureau, (1987: 62-3), and the National Policy on Education (1998), p. 9, paragraph 14.

The language policy recognizes the multi-dimensional, multi-ethnic, and, ipso facto, the multi-lingual, three-tiered political polity of Nigeria. The policy also provides for:

(1) Mother-Tongue $\left(\mathrm{L}_{1} \mathrm{MT}\right)$ and/or Language of the Immediate Community (LIC) as the language of initial literacy and of adult and non-formal education;

(2) The three major (national) languages-Hausa, Igbo, and Yoruba as $\mathrm{L}_{2}$ - as the languages of national culture and integration;

(3) English — the official language —as the language of formal literacy, the bureaucracy, secondary and higher education, the law courts, etc.;

(4) Selected foreign languages, especially, French even if now a second official language, and Arabic (as languages of international communication and discourse for which the Federal Government has approved the setting up of “Language Villages”).

In terms of the unstated policy, the policy on languages:

(1) Advocates multilingualism as the national goal;

(2) Recognizes English as the de facto official language in the bureaucracy and all tiers of formal education, and to which French is now a co-official language;

(3) Treats Hausa, Igbo, and Yoruba as potential national languages which are to be developed and used as $\mathrm{L}_{1}$ and $\mathrm{L}_{2}$ all through the formal educational system;

(4) All Nigerian languages as meaningful media of instruction in initial literacy and in life-long and non-formal education.

Chapter II Section 22 of the Constitution of the Federal Republic of Nigeria (1999) stipulates that Government shall promote the learning of indigenous languages. Section 22 provides that "the state shall protect, preserve, and promote the Nigerian cultures which enhance human dignity and are consistent with the fundamental objectives as provided in the chapter, i.e., the Chapter on 'Fundamental Objective and Directives principles of State Policy'”.

Section 58 of the Constitution has it that: "the business of the National Assembly shall be conducted in English and in Hausa, Igbo, and Yoruba when adequate arrangements have been made thereof”.

In the case of the House of assembly, the Constitution in Section 100 provides that: 
the business of the House of Assembly shall be conducted in English, but the House may, in addition to English, conduct the business of the House in one or more other languages spoken in the State as the House may by resolution approve. (Nigerian Constitution, 1999, p. 103)

Widdowson (1997) holds that in planning a language course, factors such as the special purpose, time, type of pupil and size of class for which the language is to be planned must be considered. According to Taiwo (2001) the first attempt towards solving Nigerian language problems was by Mallam Balla of Adamawa constituency in 1961, when he urged the then National Assembly to employ the use of the three major languages namely, Hausa, Igbo, and Yoruba as medium of communication of the house.

The objective of the government in formulating this policy is to preserve people's culture and for "interest of National Unity”. The aim was also to evolve a lingua franca for Nigeria. Many Nigerians are of the opinion that Nigeria should not only have political independence but language independence also. They pick holes in using English as the country's lingua franca because according to them, "as Africans we do not think English". Moreso, language and culture are inseparable and therefore to avoid overriding influence in our culture an indigenous language is preferred.

There is no gainsaying the fact that the influence of foreign language or languages has adversely affected our culture. This ranges from our mode of dressing to our general attitude to life. Our youths with unquenchable appetite have copied everything European to the detriment of our known norms and ways of life. Speaking of indigenous languages in private and public places is discouraged and anybody using them is downgraded and considered as either semi or downright illiterate. This attitude has not even changed at schools especially at the early stages of primary and secondary schools where pupils are chastised and sometimes fined some money for speaking in vernacular. This has jeopardized the efforts of developing our indigenous language and has gone contrary to the Nigerian Language Policy which encourages the use of such languages at that levels of learning and public places.

This trend should give concern to Nigerian linguists in particular and all other Nigerians because if the trend is not halted early enough, we all will be losers. Nigeria has become a good consumer of information technology. And this is an essential ingredient of globalization. As we pointed out earlier, with Nigeria continuing to "think English" her hopes to tap all the benefits of new information technology embodied in globalization remains a ruse.

Technological innovation has given concreteness to globalization. Global reach has been achieved by innovations in telecommunications, computerization, air travels, etc. Through the website, it is possible for a company to create big markets irrespective of where it is located in the world. Also millions of dollars and Euros exchange hands between business individuals and organizations in any part of the world through electronic transfer. Through website also, information about international conferences can be sought for without one having to travel. With globalization there are no longer country differences but customer and people differences because borders have been transcended. It is however important to realize that the extent to which a country can participate in the globalizing market depends on its technological capacity. With Nigeria's technical backwardness and inability to fully develop her national languages which is the bedrock for human development, there is fear on the level of preparedness of the country for globalization.

Attention should also be drawn to the effect of globalization on cultural life of Nigeria vis-à-vis Africa. Akindele and Ate (2000) say that with globalization, there is the tendency that cultural differences between countries and their people are deemphasized in their interactions. This is to say, the culture that will permit 
globalization to take place will be one that is supra-state to which no country, nor group of people, can lay claim. To the extent of correctness of this opinion the question then is: Does this augur well for Nigerian and African culture? Obviously, the answer is No. People are never isolated from their inherent cultures. If globalization can remodel, for example, a Nigerian to be a Nigerian in outlook but an American or European in attitude, one cannot less but agree that globalization reinforces cultural imperialism-one of the crimes of colonialism. Henriot (2000) argues that traditional African cultures (there are many cultures in Africa, not simply one) emphasize values such as community, family, respect of life, hospitality. But these cultural values come into strong confrontation with the values communicated through Western music, movies, videos, cable and satellite television, advertisements, and the idolized figures of entertainment and sports. If all peoples must jealously guide and defend their cultures therefore, checks on infiltration of these external negative influences must be mounted and strictly too.

\section{Prospects of Developing Nigerian Language or Languages for Globalization}

Emenanjo (2001) correctly observed that the future of Nigeria as a strong, indivisible and virile African nation unencumbered by the many trappings of neo-colonialism lies, to some extent, with how seriously her indigenous languages (and cultures) are developed and used as media of communication in our work-a-day lives and in academic and scientific discourse. English can help us realize all the fundamental objectives—political, economic, social and educational—of the Nigerian nation. But English is an elastic language spoken by not up to 20 percent of the Nigerian population. Therefore, the only option left for the country is absolute resolve to develop the indigenous languages and make them usable not only nationally but also globally. This is a task before our linguists and scientists. The idea of seeing users of the indigenous languages as inferiors should be unequivocally condemned. Efforts must be convincingly made by policy makers of the country that the national languages are used in wider scope than it is presently done. It is quite commendable the initiative of one of our renowned scientist Mr. Leo Ekeh, who produced a brand of computer with the naira sign in the keyboard. Many Nigerians are impatiently waiting for more of such innovations. It is only through such challenges that the languages, cultures, and peoples of Nigeria can be gradually brought into lime-light to fully measure up with globalization.

There should be a national sociolinguistic survey of Nigeria. This exercise will enable Nigerians to know the actual number of languages both Nigerian and other languages in use in the country. Other vital information about the languages; their locations, indigenous and pejorative names, how many people that speak them with regard to $\mathrm{L}_{1}, \mathrm{~L}_{2}, \mathrm{~L}_{3}$, the extent and degree of their usage in formal education, in the electronic and print media, the law courts, etc. The importance of this was pointed out by Ferguson (1966) who insisted that "no meaningful language planning can go in any country, without a reliable sociolinguistic survey in the same way that no meaningful socio-economic planning can go on without a reliable census”. The data from this survey should help in putting in place a more realistic and comprehensive language policy for the country. Further steps must be taken to have this policy documented in one document. This will encourage strict adherence and references could be made to it.

The task of developing indigenous languages of the country must be a joint efforts of both the federal government, state and local governments including educational establishment at all levels. More institutes for Nigerian languages should be established in the country and in the interim; the ones in existence should be well funded. Furthermore, awareness campaign should be created on the existence of these institutes and make them 
assessable to all who might need their services.

\section{Conclusion}

In conclusion, one can emphatically say that there are prospects for growth and development of the country's national languages. The above mentioned steps if judiciously adopted will be in no distant time place Nigerian languages in world's collection of useful and usable languages. By then, globalization will be more meaningful not only to Nigeria but Africa.

\section{References}

Adekunle, M. A. (1972). Multilingualism and language function. Nigeria African Studies Review, 15(2), 185-207.

Agheyisi, R. N. (1986). Minor languages and national question: Prospects and problems. Proceedings from the National Symposium on Nation Question. Abuja.

Akindele, R. A., \& Ate, B. E. (2000). Selected readings on foreign policy and international relations. NIIA Enlightenment Course Series, 1(1), 204.

Banjo, A. (1995). On codifying Nigerian English: Research so far. In A. Bamgbose, A. Banjo, \& A. Thomas (Eds.), New Englishes: A West African Perspective (pp. 67-80). Ibadan: Mosuro.

Brann, C. M. B. (1977). Language planning for education in the 80s: Some demographic, linguistic and areal factors. In A. Bangbose (Ed.), Language in Education in Nigeria: Proceedings of the Language Symposium (pp. 47-61).

Brann, C. M. B. (1986). The Role and Function of Language in Government in Nigeria (Mimeo), Lagos.

Brann, C. M. B. (1989). Lingua minor, Franca and nationalist. In U. Ammon (Ed.), Status and function of languages and language varieties (pp. 372-385). Berlin and New York: Walder de Gruyter.

Chumbow, B. S. (1982). Discovering the link between national development, education and language. In B. S. Chumbow (Ed.), National development, education and language in Southern Africa. London. Heinemann.

Chumbow, B. S. (1990). The place of the mother tongue in the national policy on education. In E. N. Emenanjo (Ed.), Multilingualism, minority languages and language policy in Nigeria. Agbor: Central Books Limited.

Emenajo, E. N. (2001). Multilingualism: Asset or liability. Proceedings from 10th Modern Languages Association Conference at the Nigerian French Language Village.

Emenanjo, E. N. (1986). Language and the National Question: Multilingualism as a National Asset in Nigeria. Proceedings from the Seminar on the National Question in Nigeria: Its Historical Origin and Contemporary Dimension.

Emenanjo, E. N. (1990). Multilingualism Minority languages and language policy in Nigeria. Linguistic Association of Nigeria in Association with Central Books, Agbor.

Emenanjo, E. N. (2001). How Many Nigerian Languages Are There?: Issues on the definition and Identification of Language (mimeo). Ibadan. Oxford University Press.

Ferguson, C. (1966). “National Sociolinguistic Profile Formulas” in W. Bright (ed.) 309 - 323.

Ferguson, C. (1968). Language development. In J. A. Fishman, C. A. Ferguson, \& J. Das Gupta (Eds.), Language problems of developing nations (pp. 27-35). New York: Wiley \& Sons.

Henriot, P.J. (2000). Globalization: Implication for Africa. Retrieved from http://www.sedos.org/english/global.html

Olagoke, D. O. (1980). Lexical deviation in Nigerian English. JLAC, 2(3\&4), 35-57.

Osaji, D. (1979a). Language survey in Nigeria. Quebec: ICRBC.

Osaji, D. (1979b). Language survey in Nigeria (pp. 13-188). Quebec: ICRD Publications.

Taiwo, O. (2001). Trends in English literary studies in Nigerian Universities (Monograph, unpublished).

Williamson, K. (1983). Practical orthography in Nigeria. Ibadan: Heinemann Educational Books (Nigeria) Limited.

Winddowson, H. (1997). EIL, ESL, EFL, global issues and local interests. World Englishes, 16, 135-146. 